\title{
Contaminant Properties of Hospital Clinical Laboratory Wastewater: A Physiochemical and Microbiological Assessment
}

\author{
Beril Salman Akin \\ Department of Environmental Sciences, Institute of Sciences and Technology, Gazi University, Teknikokullar, \\ Turkey \\ Email: bsakin@gazi.edu.tr
}

Received 9 February 2016; accepted 4 April 2016; published 7 April 2016

Copyright (C) 2016 by author and Scientific Research Publishing Inc.

This work is licensed under the Creative Commons Attribution International License (CC BY).

http://creativecommons.org/licenses/by/4.0/

(c) (i)

Open Access

\begin{abstract}
Hospital laboratory wastewater has been considered to significantly change the degree of contamination of especially the hospital wastewater. The present study investigated the hospital clinical laboratory wastewater and the pollution loads were assessed for pathogens, heavy metals, and organic materials. Composite samples were collected from clinical laboratory wastewater of a 350-bed hospital for a six-month period. Analyses for pH, TSS (Total Suspended Solid), BOD (Biochemical Oxygen Demand), $\mathrm{COD}$ (Chemical Oxygen Demand), $\mathrm{PO}_{4}-\mathrm{P}$, and $\mathrm{Cl}$ as well as heavy metals ( $\mathrm{Cd}, \mathrm{Pb}, \mathrm{Zn}, \mathrm{Cu}, \mathrm{Cr}, \mathrm{Co}, \mathrm{Ni}, \mathrm{Al}$, and $\mathrm{Mn}$ ) were made in order to physiochemical properties of the samples. Bacterial isolation (Pseudomonas aeruginosa, Escherichia coli, Acinetobaumanii, CNS-CoagulaseNegative Staphylococcus) and antigen-antibody analyses were conducted in order to find the microbiological pollution load of the wastewater. As a result of the study it was found that the hospital clinical laboratory wastewater was alkaline and COD/BOD ratio reached to a range of 10 - 12 in the wastewater. It was concluded that although the heavy metal concentrations were within the sewage discharge limits the said levels could pose health risk. It was also found that the wastewater entailed health risk due to pathogens.
\end{abstract}

\section{Keywords}

Hospital Wastewater, Heavy Metal, Water Quality, Bacterial Isolation

\section{Introduction}

Although the recent years witnessed increased focus on hospital waste management throughout the world, the

How to cite this paper: Akin, B.S. (2016) Contaminant Properties of Hospital Clinical Laboratory Wastewater: A Physiochemical and Microbiological Assessment. Journal of Environmental Protection, 7, 635-642.

http://dx.doi.org/10.4236/jep.2016.75057 
number of studies as regards management and treatment of wastewater due to hospital and biochemistry, microbiology etc. clinical laboratories remained limited. Hospital wastewater includes macro- and micro-pollutants of wide concentration range from laboratories, research units, operation rooms, units, where medicine and nutrition solutions are prepared, and polyclinics [1]. Especially the pharmaceuticals are the hospital-originated micropollutants substantially used in modern medical practices. Depending upon the number of beds, hospitals consume water in a day, ranging from 400 to $1200 \mathrm{~L} /$ day/bed [2]. As a result of such consumption, the wastewater contains significant amounts of microorganisms, heavy metals, toxic chemicals, and radioactive elements. Hospital-originated wastewater is discharged to city sewage systems in many countries, treated together with domestic wastewater, and discharged to receiving environments [3]. One of the main complications of the said process is that hospital wastewater is discharged to sewage systems without a specific pretreatment.

Studies have suggested that even the pretreatment of hospital wastewater prior to discharge to domestic wastewater sewage systems for treatment might not be a sufficient solution due to the micro-pollutant content of hospital wastewater [4]-[6]. Especially the fact that pharmaceutical-originated micro-pollutants have significantly lower concentrations $\left(10^{-3}-10^{-6} \mathrm{mg} / \mathrm{L}\right.$ ) and different characteristics (dissolubility, volatility, absorbability, biological degradation, stability, etc.) compared to other macro-pollutants in the hospital wastewater (Biochemical Oxygen Demand-BOD, Chemical Oxygen Demand-COD, nitrogen, phosphor, etc.), leads to highly lower levels of treatability in the conventional domestic wastewater treatment facilities [1]. Today, there is an accelerated search for alternative solutions for the management and treatment of hospital wastewater especially in the developed countries based on the evidence as regards the toxic effect of the micro-pollutants on human health and environment.

Infected wastewater is generally originated from water consumption of patients and analyses of patient urine, feces, and blood samples. Today viral diseases rather than infectious diseases caused by bacteria and parasites are at the forefront. Viral infection due to viral hepatitis is the leading viral disease. Mostly transmitted by direct blood contact among human beings, today hepatitis B, hepatitis C, and HIV infections are life threatening yet easy-toprevent infections if necessary precautions are taken. Viral hepatitis agents are contained in a substantial part of medical waste from public and private hospital laboratories and other private and public laboratories, and public and private dialysis centers. Hospital laboratory wastewater is considered a mixture of pathogen microorganisms. The genetic structure of such microorganisms may be altered by the direct or indirect effect of wastewater components and lead to bacteria with high antibiotic resistance [7]. Many developed countries required disinfection of hospital wastewater before being discharged into sewage systems. Currently the most commonly used disinfectants are liquid chlorine, $\mathrm{NaClO}, \mathrm{ClO}_{2}$, and $\mathrm{O}_{3}$.

Medical wastewater originated from hospital laboratories has the potential to pose serious threat in terms of spread and contagiousness of infectious diseases for patients in the healthcare units, hospital employees, society, and the environment. The medical wastewater of hospitals and laboratories contains such pathogen, infectious agent bacteria as Salmonella spp., Shigella spp. as well as many other different microorganisms with multiple drug resistance (MDR) (Pseudomonas spp., Acinetobacter spp., Enterococcus spp., and S. aureus spp. etc.). Previous studies frequently isolated such frequently occurring nosocomial infectious agents as Bacillus spp., Staphylococcus spp., Streptococcus spp. (5\% - 10\%), E. coli (Escherichia coli), Pseudomonas aeruginosa, and Candida albicans as well as other less frequent nosocomial pathogens as Klebsiella spp., Proteus spp., and Enterobacter spp. [8]. Furthermore, it was reported that prevalence of MDR bacteria in medical wastewater of hospitals varied between $0.58 \%$ - $40 \%$ [9].

The fact that hospital wastewater contains enterobacteria and enteric pathogens, poses a risk for public health. Today, the marked increase in antibiotic resistance of infectious agent pathogen bacteria seen both in nosocomial and community-acquired infections is one of the most important problems [9] [10]. Furthermore, transmission of antibiotic resistance genes to other infectious agent bacteria constitutes a more significant public health problem [9]. Metal and heavy metal ions are the most important micro-pollutant group in the hospital wastewater. Majority of these pollutants are able to readily inhibit the biological activity at treatment systems. As a matter of fact, heavy metals pose threat to environment and human health since they are not biologically degradable pollutants and that they are movable pollutant sources [11] [12].

Studies suggested that hospital wastewater was generally of similar nature with domestic wastewater [1] [11]. Generally pollutant concentrations of BOD, COD, TSS (Total Suspended Solids) etc. are 2 - 3 times higher in hospital wastewater compared to domestic wastewater, where micro-pollutant, heavy metal, and pathogen concentrations are at higher amounts [1] [13] [14]. Majority of macro- and micro-pollutants contained in hospital 
wastewater are discharged in urban wastewater treatment systems without any pretreatment in many cases in Turkey and throughout the world, which reach to receiving environments without being metabolized and thus creating serious long-term problems [14]. Water samples are generally collected from the wastewater sewage connection nod in the studies investigating hospital wastewater properties and pollution loads. There are only a limited number of studies, which conducted separate classification and quality studies on wastewater sources in the hospital. The present study investigated hospital clinical laboratory wastewater, which was considered to have substantially changed the degree of contamination of hospital wastewater, and the pollution loads were assessed for pathogens, heavy metals, and organic materials.

\section{Material Methods}

\subsection{Study Area}

This research was conducted at the Central Laboratory of 350-bed capacity Keçiören Training and Research Hospital (Ankara, Turkey). Patients and samples are assessed via advanced technological applications in the hospital under Pathology, Radiology, Biochemistry, and Microbiology branches. A monthly average of 200 thousand biochemical and serological tests, and 20 thousand culture and manual tests are conducted at the central laboratory of the hospital. Based on an average 8-hour operation time, the devices used in the clinical laboratory of the hospital produce 561.06 liters of wastewater daily (Table 1). During the laboratory analyses, concentrated reagents are averagely diluted 20 to 1000 times subsequent to measurement and washout processes. Total serum is diluted to 10.000 times and a patient sample is diluted to 1.000 .000 to 2.000 .000 times. Therefore the wastewater amount reaches to substantial levels depending on the devices. According to the differences in the number of patients, the hospitals create an average of 500 to 1000 liters wastewater daily.

\subsection{Sample Collection}

Wastewater from laboratory environment is collected in a storage tank via closed loop collection line. The wastewater is discharged to sewage system after disinfection and neutralization process. In the scope of the experimental studies, wastewater samples were collected from the storage tank as 24-hour composite samples. Monthly sample collection continued for 6 months. The samples were carried to the laboratory in storage boxes, which comply with the Standard Methods [15] and appropriate conservation criteria (cooler storage boxes, acidification, etc.) [16].

\subsection{Physiochemical and Heavy Metal Analyses}

Cadmium (Cd), lead $(\mathrm{Pb})$, zinc ( $\mathrm{Zn})$, copper $(\mathrm{Cu})$, chromium (Cr), cobalt (Co), nickel (Ni), aluminum (Al), and manganese (Mn) analyses were made in the scope of the study. Samples collected for heavy metal analyses were placed in polyethylene vials and the medium was acidified by adding $1 \% \mathrm{HNHNO}_{3}$. The biological activity of organisms and bacteria was thus terminated in order to transformation into forms other than metals. Samples were kept in fridge at $-80^{\circ} \mathrm{C}$ [17]. Upon collection of all the samples, analyses were made at the same time. Analyses took place in the same series of study in order to avoid intra- and inter-day variation.

Table 1. Device-originated wastewater amounts at hospital clinical laboratory based on 8-hour operation performance.

\begin{tabular}{cc} 
Device & Wastewater amount (L/day) \\
Routine Biochemistry & 466.7 \\
Immunoassay devices & 44.7 \\
Complete Blood Device & 33.3 \\
Urine Analyzers & 5.3 \\
Coagulation Devices & 5.83 \\
HPLC and Chromatography & 2 \\
Blood Gas & 0.23 \\
TOTAL & 561.06 \\
\hline
\end{tabular}


Agilent 7500 CXICP-MS device was used in metal analyses of water samples and the analyses were conducted according to the Standard Methods [15]. 99.99\% pure Argon gas was used for ionization of metals. Standard solutions at different concentrations of heavy metals were first prepared and measured at ICP-MS and the heavy metal concentrations in the samples were expressed in $\mathrm{mg} / \mathrm{L}$ levels. Detector calibration was made by replicate and wave length calibration was made by $1 \mathrm{mg} / \mathrm{L} \mathrm{Li}, \mathrm{Ce}, \mathrm{Y}, \mathrm{Tl}$ (Merck) adjustment solutions before commencing analyses at ICP device. Upon calibration, a method was developed by entering the names of elements to be analyzed, appropriate wavelengths for the selected element, standard calibration solution concentrations and numbers, and the number of samples in the ICP program. Analyses were conducted after replicate, standard calibration solutions, and samples were placed in the tubes in the automatic sampler. Certified standard solutions of analytical purity were used as standard calibration solutions. Device operation standard solutions were prepared by 5, 10, 15, 20, $25 \mu \mathrm{g} / \mathrm{L}$ concentrations of $1000 \mathrm{ppm}$ arsenic (As), mercury (Hg), and zinc (Zn) stock standard solutions. $\mathrm{HNO}_{3}$ added to have $65 \%$ concentration. The replicate sample was also prepared by adding $\mathrm{HNO}_{3}$ of $65 \%$ concentration to double distilled water. Separate calibration graphs were produced for each element by the use of a minimum of 5 standards and absorbance for standards were plotted in the graph against the standard concentration.

\subsection{Microbiological Analyses}

In order to determine the quantity of total bacteria in the collected water samples, 6 series of dilutions were prepared; upon which $1 \mathrm{ml}$ from each sample were inoculated in agar with 5\% sheep blood. The agar plates were incubated in aerobic environment for 24 to 48 hours at $37^{\circ} \mathrm{C}$. Furthermore, selective media were also inoculated besides agar with $5 \%$ sheep blood for determination of bacterial variety. For the purpose thereof, following inoculations, with the use of quantitative method, were conducted: Eosin Methylene Blue for determination of enteric bacteria, Bile Esculin Azide Agar with 100 mg/ml Azide for enterococci, Hektoen Enteric Agar and Chromogenic Salmonella plus Agar for Salmonella spp.-Shigella spp., Sabouraud Dextrose Agar for possible fungi growth, Specific Chromogenic Pseudomanas Agar for Pseudomonas spp., and finally Chromogenic E. coli Agar for $E$. coli. The inoculated media were incubated in aerobic environment for 24 to 48 hours at $37^{\circ} \mathrm{C}$. The media were inspected at 24th and 48th hours of incubation [17] [18].

Bacterial suspensions were prepared in sterile tubes upon collection of preliminary information about bacteria through Gram Staining, Catalase Test for Gram positive bacteria and Oxidase Test for Gram Negative bacteria. The turbidity degree of suspensions were set to Mac Farland standard 0.5 by means of DensiCheck (BioMerieux) and advance identification processes were held using Vitec 2 GP card for Gram positive bacteria, and Vitec 2 GN card for Gram negative bacteria at Vitec 2 Compact (Biomerieux) automated system. The bacteria were identified in terms of types and species [17] [18].

Antigen and Antibody determination: HbsAg, Anti-HCV, Anti-HIV, Toxoplasma IgM, Rubella IgM AND CMV IgM concentration was measured with automatic diagnostic system (Architect system, Abbott Diagnostics, U.S.A). The Architect system HbsAg, Anti-HCV, Anti-HIV, Toxoplasma IgM, Rubella IgM, CMV IgM assays, uses chemiluminescent immunoassay (CLIA) technology for the quantitative determination of hepatitis B surface antigen and antibody, hepatitis C antibody, HIV p24 antigen and HIV-1 and HIV-2 antibody, Toxoplasma gondii against formed IgM antibody, Rubella virus IgM antibody, CMV IgM antibody.

\section{Results and Discussion}

\subsection{Physiochemical Analyses}

The findings of the physiochemical and heavy metal analyses for determining the characterization of hospital clinical laboratory wastewater were provided in Table 2. Wastewater $\mathrm{pH}$ values varied between 7.9 and 9.4 during the 6-month observation period. Hospital wastewater is generally alkaline. Nevertheless, intensive use of disinfectants may be associated with a change in $\mathrm{pH}$ value between different ranges. Therefore, different levels of $\mathrm{pH}$ change in hospital wastewater have been observed in different studies: 6.2 - 7.1 [19], 5.1 - 10.4 [20], and 7 - 8 [21]. The present study on clinical laboratory wastewater also observed alkaline nature of the wastewater.

It was reported that hospital wastewater had generally similar characteristics with domestic wastewater as regards BOD, COD, and SS concentrations [7] [19] [22]. The findings of the present study suggested that COD/ BOD ratio might vary between 2 to 3. This study observed that average BOD and COD values for a six-month period were $75.3 \mathrm{mg} / \mathrm{L}$, and $934.2 \mathrm{mg} / \mathrm{L}$ respectively. As a result, it was seen that COD/BOD ratio could reach to 
a range of 10 to 12 in hospital clinical laboratory wastewater (Table 2). This suggested that mostly the laboratories accounted for the amount of chemically oxidizable organic matter in the hospital wastewater.TSS value varied between 98 - $162 \mathrm{mg} / \mathrm{L}$ ranges in the hospital laboratory wastewater (Table 2). Other studies reported higher values for TSS in hospital wastewater: 155 - $298 \mathrm{mg} / \mathrm{L} \mathrm{[13],} 539 \mathrm{mg} / \mathrm{L}$ [7], and 72-243 mg/L [23]. The present study on laboratory clinical wastewater found that $\mathrm{Cl}$ and phosphate amounts in the wastewater were in the range of $129-156 \mathrm{mmol} / \mathrm{L}$, and $15-30 \mathrm{mg} / \mathrm{L}$ respectively. It was suggested that $\mathrm{Cl}$ and phosphate might be originated from the kits used in devices and patient serums. Studies on hospital wastewater reported that $\mathrm{Cl}$ value might reach to higher concentrations between the ranges of 63.4 - $359.2 \mathrm{mg} / \mathrm{L}$, especially due to the disinfectants [13].

\subsection{Heavy Metals}

Cadmium (Cd), lead $(\mathrm{Pb})$, zinc $(\mathrm{Zn})$, copper $(\mathrm{Cu})$, chromium (Cr), cobalt (Co), nickel (Ni), aluminum (Al), and manganese $(\mathrm{Mn})$ in the hospital laboratory wastewater were measured for a six-month period in the scope of the study. Heavy metal concentrations based on analyses on monthly collected samples were provided in Table 3. Upon observation of the laboratory wastewater, copper had the highest concentration. $\mathrm{Cu}$ values varied between 0.44 and $0.85 \mathrm{mg} / \mathrm{L}$, where the average $\mathrm{Al}, \mathrm{Cr}$, Cd, and $\mathrm{Zn}$ values were measured as $0.06,0.07,0.02$,and 0.07 $\mathrm{mg} / \mathrm{Lin}$ six-month period, and $\mathrm{Mn}, \mathrm{Co}, \mathrm{Ni}$, and $\mathrm{Zn}$ values were $<0.01$.

Limit values that must be met by wastewater to be discharged to sewage system were determined pursuant to the Regulation of Wastewater Discharge into Sewage System in force in Turkey and Table 25 of the Regulation on Prevention of Water Pollution (Wastewater Standards Required for Discharge of Wastewater in Wastewater Infrastructure Facilities) [24]. In the scope of the aforementioned regulations the $\mathrm{Pb}, \mathrm{Cd}, \mathrm{Zn}, \mathrm{Cu}, \mathrm{Ni}$, and $\mathrm{Cr}$ concentrations were within the limits required for direct discharge. However, those regulations did not provide a standard value for $\mathrm{Co}, \mathrm{Mn}$, and $\mathrm{Al}$.

Table 2. Results of physiochemical and heavy metal analysis of hospital laboratory wastewater.

\begin{tabular}{cccccccccc}
\hline Parameters & January & February & March & April & May & June & Max. & Min. & Avg. \\
\hline $\mathrm{pH}$ & 7.9 & 8.2 & 8.7 & 9.0 & 9.4 & 8.9 & 9.4 & 7.9 & 8.7 \\
$\mathrm{Cl}(\mathrm{mmol} / \mathrm{L})$ & 129 & 130 & 138 & 136 & 141 & 156 & 156 & 129 & 138.3 \\
$\mathrm{PO}_{4}$-P (mg/L) & 15 & 16 & 21 & 25 & 28 & 30 & 30 & 15 & 22.5 \\
$\mathrm{BOD}(\mathrm{mg} / \mathrm{L})$ & 63 & 74 & 89 & 103 & 101 & 112 & 112 & 63 & 75.3 \\
$\mathrm{COD}(\mathrm{mg} / \mathrm{L})$ & 769 & 865 & 896 & 925 & 1127 & 1023 & 1127 & 769 & 934.2 \\
TSS (mg/L) & 102 & 113 & 98 & 121 & 162 & 148 & 162 & 98 & 124 \\
\hline
\end{tabular}

Table 3. Results of heavy metal analysis of hospital laboratory wastewater.

\begin{tabular}{ccccccccccc}
\hline $\begin{array}{c}\text { Parameters } \\
(\mathrm{mg} / \mathrm{L})\end{array}$ & January & February & March & April & May & June & Max. & Min. & Avg. \\
\hline $\mathrm{Al}$ & 0.056 & 0.056 & 0.061 & 0.071 & 0.046 & 0.065 & 0.071 & 0.046 & 0.059 \\
$\mathrm{Cr}$ & 0.076 & 0.076 & 0.075 & 0.095 & 0.034 & 0.082 & 0.095 & 0.034 & 0.073 \\
$\mathrm{Mn}$ & 0.005 & 0.005 & 0.005 & 0.004 & 0.003 & 0.003 & 0.005 & 0.003 & 0.004 \\
$\mathrm{Co}$ & 0.0002 & 0.0002 & 0.0002 & 0.0003 & 0.0004 & 0.0002 & 0.0004 & 0.0002 & 0.0003 \\
$\mathrm{Ni}$ & 0.0006 & 0.0006 & 0.0006 & 0.0009 & 0.0007 & 0.0008 & 0.0009 & 0.0006 & 0.0007 \\
$\mathrm{Cu}$ & 0.689 & 0.89 & 0.703 & 0.854 & 0.764 & 0.443 & 0.854 & 0.443 & 0.690 \\
$\mathrm{Zn}$ & 0.004 & 0.004 & 0.002 & 0.006 & 0.007 & 0.001 & 0.007 & 0.001 & 0.004 \\
$\mathrm{Cd}$ & 0.031 & 0.031 & 0.024 & 0.019 & 0.017 & 0.024 & 0.031 & 0.017 & 0.024 \\
$\mathrm{~Pb}$ & 0.084 & 0.084 & 0.075 & 0.057 & 0.068 & 0.056 & 0.084 & 0.056 & 0.071 \\
\hline
\end{tabular}


World Health Organization (WHO) [25], Turkish Standards Institution (TSE 266) [26], and USA Environmental Protection Agency (EPA) [27] provided the limit values of heavy metals in wastewater as regards human health. A comparison between the said standard values and the findings of our measurements based on the hospital clinical laboratory wastewater was provided in Table 4 . The analysis results suggested that average $\mathrm{Cd}, \mathrm{Cr}$, and $\mathrm{Pb}$ concentrations were slightly above the standard values.

Principally the chemical and analysis kits accounted for the heavy metal concentrations in the wastewater of hospital clinical laboratories. Several studies on hospital wastewater reported such heavy metals as Pb, Hg, Pt, Cd, and $\mathrm{Sr}$ in the wastewater [1] [4] [28]. Studies from the relevant literature included wastewater quality analyses for the totality of the hospital wastewater. The first ever investigation as regards the heavy metal concentrations in hospital clinical laboratory wastewater was conducted in the present study and it was found that the heavy metal levels could still pose a health risk although they were within the limits for discharge into sewage system.

\subsection{Microbiologic Analyses}

Bacterial isolation and count were conducted in the samples collected for the purpose of the study for Pseudomonas aeruginosa, Escherichia coli, Acinetobaumanii, CNS (Coagulase-negative staphylococcus) and the results were provided in Table 5. Certain levels of pathogen and antibiotic resistant bacteria were found in the samples. During the experimental studies, it was found that Pseudomonas aeruginosa, Acinetobaumanii, and Coagulasenegative staphylococcus had populations of $2 \times 10^{4}-9 \times 10^{6} \mathrm{cfu} / \mathrm{ml}, 5 \times 10^{4}-6 \times 10^{6} \mathrm{cfu} / \mathrm{ml}$, and $7 \times 10^{1}-5 \times 10^{2}$ $\mathrm{cfu} / \mathrm{mL}$ respectively. These pathogen organisms may pose important risk to human health. These organisms were also reported in studies on hospital wastewater [13] [22] [29].

E. coli levels varied between $9 \times 10^{2}$ and $8 \times 10^{4} \mathrm{cfu} / \mathrm{ml}$ ranges in clinical laboratory wastewater samples. The change in bacteria levels during the six-month period was as a result of the difference in patient serum numbers. Different studies reported total coliform numbers in hospital wastewater as $10^{6}$ (colony/100ml) [1], $1 \times 10^{8}$ (colony/L) [30], $1-2.5 \times 10^{4}(\mathrm{PFU} / 100 \mathrm{ml})$ [31], $1.2-3.3 \times 10^{3}(\mathrm{MPN} / 100 \mathrm{ml})$ [22]. The values vary by such factors as number of patients and hospital capacity [32].

Antigen and antibody analyses were made for the wastewater samples. Distribution of antigens and antibodies by month was provided in Table 6. Three wastewater samples were positive for Hepatitis B antigen. Positive IgM antibody results suggested that the person in question had recent contact with the pathogen. Therefore, despite the fact that viral pathogens were not directly included in the study, the occurrence of IgM antibodies in the wastewater might be associated with the occurrence of the pathogen in the wastewater as well.

Table 4. A comparison between heavy metal measurements and national/international standards.

\begin{tabular}{ccccc}
\hline Parameter $(\mathrm{mg} / \mathrm{L})$ & TSE 266 & WHO & EPA & Present Ptudy \\
$\mathrm{Cd}$ & 0.01 & 0.01 & 0.01 & 0.024 \\
$\mathrm{Cr}$ & 0.05 & 0.05 & 0.05 & 0.073 \\
$\mathrm{Co}$ & 0.01 & 0.01 & 0.01 & 0.0003 \\
$\mathrm{Cu}$ & 3.00 & - & - & 0.690 \\
$\mathrm{Mn}$ & 0,10 & 0.05 & 0.05 & 0.004 \\
$\mathrm{Ni}$ & 0.02 & 0.02 & 0.02 & 0.0007 \\
$\mathrm{~Pb}$ & 0.05 & 0.05 & 0.05 & 0.071 \\
$\mathrm{Zn}$ & 5.00 & - & 5.00 & 0.004 \\
\hline
\end{tabular}

Table 5. Result of bacterial isolates of hospital laboratory wastewater (cfu/mL).

\begin{tabular}{ccccccc}
\hline & January & February & March & April & May & \\
\hline Pseudomonas aeruginosa & $9 \times 10^{6}$ & $5 \times 10^{6}$ & $3 \times 10^{5}$ & $2 \times 10^{4}$ & $4 \times 10^{6}$ & $6 \times 10^{5}$ \\
Escherichia coli & $3 \times 10^{3}$ & $6 \times 10^{4}$ & $2 \times 10^{4}$ & $9 \times 10^{2}$ & $7 \times 10^{3}$ & $8 \times 10^{4}$ \\
Acinetobaumanii & $5 \times 10^{4}$ & $6 \times 10^{6}$ & $4 \times 10^{6}$ & $6 \times 10^{5}$ & $5 \times 10^{5}$ & $3 \times 10^{6}$ \\
CNS (Coagulase-negative staphylococcus) & $2 \times 10^{2}$ & $3 \times 10^{2}$ & $2 \times 10^{3}$ & $7 \times 10^{1}$ & $5 \times 10^{2}$ & $4 \times 10^{2}$ \\
\hline
\end{tabular}


Table 6. Frequency of distribution antigen and antibody.

\begin{tabular}{ccccccc}
\hline & January & February & March & April & May & June \\
Anti-HCV & - & - & - & - & + & + \\
Anti-HIV & - & - & - & - & - & - \\
HBsAg & + & - & - & + & + & - \\
HAV-IgM & + & + & - & - & - & - \\
Toxoplazma-IgM & + & - & - & - & - & - \\
Rubella-IgM & - & - & - & + & - & - \\
CMV-IgM & - & - & + & + & - & - \\
\hline
\end{tabular}

+Reactive, -Nonreactive.

\section{Conclusion}

The present study aimed to investigate the general pollution load of hospital clinical laboratory wastewater, first of its kind in the relevant literature. Wastewater of the clinical laboratory of a 350-bed hospital was analyzed for a six-month observation period. As a result of the study it was found that COD/BOD ratio was very high in the hospital clinical laboratory wastewater. Furthermore, it was seen that concentrations of heavy metal that could be hazardous for human health were above the standard limits. Upon the analyses it was seen that there were high levels of pathogen organisms in the wastewater. Moreover, despite the viral pathogens were not included in the study, the occurrence of IgM antibodies was an indication of pathogens in the wastewater. The results of the present study clearly demonstrated that the hospital clinical laboratory wastewater substantially increased the pollution load of the entire hospital wastewater.

\section{References}

[1] Verlicchi, P.,Galletti, A., Petrovic, M. and Barcelo, D. (2010) Hospital Effluents as a Source of Emerging Pollutants: An Overview of Micropollutants and Sustainable Treatment Options. Journal of Hydrology, 389, 416-428. http://dx.doi.org/10.1016/j.jhydrol.2010.06.005

[2] Sharma, P, Mathur, N., Singh, A. And Bhatnagar, P. (2014) Physico-Chemical Assessment of Hospital Wastewater Quality. International Journal of Development Research, 9, 1915-1918.

[3] Gautam, A.K., Kumar, S. and Sabumon, P.C. (2007) Preliminary Study of Physico-Chemical Treatment Options for Hospital Wastewater. Journal of Environmental Management, 83, 298-306. http://dx.doi.org/10.1016/j.jenvman.2006.03.009

[4] Altın, A., Altın, S. and Değirmenci, M. (2003) Characteristics and Treatability of Hospital (Medical) Wastewaters. Fresenius Environmental Bulletin, 12, 1098-1108.

[5] Pauwels, B. And Verstraete, W. (2006) Thetreatment of Hospital Wastewater: An Appraisal. Journal of Water and Health, 4, 405-416.

[6] Vieno, N. (2007) Occurrence of Pharmaceuticals in Finnish Sewage Treatment Plants, Surface Waters, and Their Elimination in Drinking Water Treatment Processes. PhD Thesis, Tampere University of Technology, Tampere, p. 130.

[7] Berto, J., Rochenbach, G.C., Barreiros, M.A.B., Correa, A.X.R., Peluso-Silva, S. and Radetski, C.M. (2009) PhysicoChemical Microbiological and Ecotoxicological Evaluation of a Septic Tank/Fenton Reaction Combination for the Treatment of Hospital Wastewaters. Ecotoxicology and Environment Safety, 72, 1076-1081. http://dx.doi.org/10.1016/j.ecoenv.2008.12.002

[8] Oyeleke, S.B.,Istifanus, N. and Manga, S.B. (2008) The Effects of Hospital Solid Waste on the Receiving Environment. International Journal of Integrative Biology, 3, 191-195.

[9] Chitnis, V., Chitnis, D.S., Patil, S. and Kant, R. (2000) Hospital Effluent: A Source of Multiple Drug Resistant Bacteria. Current Science, 79, 989-991.

[10] Stuart, B. (2002) Factors İmpacting on the Problem of Antibiotic Resistance. Journal of Antimicrobial Chemotherapy, 1, 25-30.

[11] Emmanuel, E., Pierre, M.G. and Perrodin, Y. (2009) Groundwater Contamination by Microbiological and Chemical Substances Released from Hospital Wastewater: Health Risk Assessment for Drinking Water Consumers. Environment 
International, 35, 718-726. http://dx.doi.org/10.1016/j.envint.2009.01.011

[12] Ortega, L.M., Lebrun, R., Blais, J.F. and Hausler, R. (2008) Removal of Metal Ionsfrom an Acidic Leachate Solution by Nanofiltration Membranes. Desalination, 227, 204-216. http://dx.doi.org/10.1016/j.desal.2007.06.026

[13] Emmanuel, E., Keck, G., Blanchard, J., Blanchard, J., Vermande, P. and Perrodin, Y. (2004) Toxicological Effects of Disinfections Using Sodium Hypochlorite on Aquatic Organisms and İts Contribution to AOX Formation in Hospital Wastewater. Environment International, 30, 891-900. http://dx.doi.org/10.1016/j.envint.2004.02.004

[14] Yaşar, A., Can Doğan, E. and Arslan A. (2013) Macro and Micro Pollutants and Treatment Options in Hospital Wastewaters. Erciyes University Journal of the Institute of Science and Technology, 2, 144-158.

[15] APHA (2005) Standard Methods for the Examination of Water and Wastewater. 21st Edition, American Public Health Association, Washington, p. 6710.

[16] Akın, B.S. and Ugurlu, A. (2005) Monitoring and Control of Biological Nutrient Removal in a Sequencing Batch Reactor. Process Biochemistry, 40, 2873-2878. http://dx.doi.org/10.1016/j.procbio.2005.01.001

[17] Gerhardt, P., Murray, R.G.E., Wood, W.A. and Krieg, N.R. (1994) Methods for General and Molecular Bacteriology. ASM Press, Washington DC, 791.

[18] Garcia, L.S. and Isenberg, H.D. (2010) Clinical Microbiology Procedures Handbook. Third Edition, ASM Press, Washington DC.

[19] Wen, X., Ding, H., Huang, X. and Liu, R. (2004) Treatment of Hospital Wastewater Using a Submerged Membrane Bioreactor. Process Biochemistry, 39, 1427-1431. http://dx.doi.org/10.1016/S0032-9592(03)00277-2

[20] Gusbeth, C., Frey, W., Volkmann, H., Schwartz, T. and Bluhm, H. (2009) Pulsed Electric Field Treatment for Bacteria Reduction and Its Impact on Hospital Wastewater. Chemosphere, 75, 228-233. http://dx.doi.org/10.1016/j.chemosphere.2008.11.066

[21] Marcelo, L., Wilde, S.M. and Ayrton, F.M. (2013) Degradation of $\beta$-Blockers in Hospital Wastewater by Means of Ozonation and $\mathrm{Fe}^{2+}$ /Ozonation. Water Research, 48, 280-295.

[22] Ekhaise, F.O. and Omavwoya, B.P. (2008) Influence of Hospital Wastewater Discharged from University of Benin Teaching Hospital (UBTH), Benin City on Its Receiving Environment. American-Eurasian Journal of Agricultural \& Environmental Sciences, 4, 484-488.

[23] Mesdaghinia, A.R., Naddafi, K., Nabizadeh, R., Saeedi, R. and Zamanzadeh, M. (2009) Wastewater Characteristics and Appropriate Method for Wastewater Management in the Hospitals. Iranian Journal of Public Health, 38, 34-40.

[24] WPCR (2004) Water Pollution Control Regulations, Number: 25687. Ministry of Environment and Forests, Ankara.

[25] WHO (1993) Guidelines for Drinking-Water Quality, Recommendations. 2nd Edition, Vol. 1, World Health Organization, Geneva, 188.

[26] Turkish Standard (1997) Sular-icme ve kullanma sulari, TS 266, 32, Ankara.

[27] EPA (United States Environmental Protection Agency) (2001) National Primary Drinking Water Standards. Office of Water, EPA 816-F-01-007, 4.

[28] Kümmerer, K., Erbe, T., Gartiser, S. and Brinker, L. (1998) AOX-Emissions from Hospitals into Municipal Wastewater. Chemosphere, 36, 2437-2445. http://dx.doi.org/10.1016/S0045-6535(97)10200-4

[29] Boillot, C., Bazin, C., Tissot-Guerraz, F., Droguet, J., Perraud, M., Cetre, J.C., Trep, D. and Perrodin, Y. (2008) Daily Physicochemical, Microbiological and Ecotoxicological Fluctuations of a Hospital Effluent According to Technical and Care Activities. Science of the Total Environment, 403, 113-129. http://dx.doi.org/10.1016/j.scitotenv.2008.04.037

[30] Steven, W.T., Judd, S.J. and Mcloughlin, B. (1998) Reduction of Fecal Coliform Bacteria in Sewage Effluents Using a Microporous Polymeric Membrane. Water Research, 32, 1417-1422. http://dx.doi.org/10.1016/S0043-1354(97)00344-8

[31] Liu, Q., Zhou, Y., Chen, L. and Zheng, X. (2010) Application of MBR for Hospital Wastewater Treatment in China. Desalination, 250, 605-608. http://dx.doi.org/10.1016/j.desal.2009.09.033

[32] Sadhana, C., Rajesh, S. and Raj, K. (2013) Quantification and Charecterization of Bio-Medical Waste at Satna City M.P. India. IOSR Journal of Environmental Science, Toxicology and Food Technology, 4, 93-98. http://dx.doi.org/10.9790/2402-0449398 